\title{
HUBUNGAN KEBIASAAN ANAK MENJAGA KESEHATAN DAN KEBERSIHAN GIGI DENGAN KARIES MOLAR PERTAMA PERMANEN PADA MURID SEKOLAH DASAR DI KECAMATAN PADANG TIMUR KOTA PADANG
}

\author{
(RELATION CHILD HABITUAL TO KEEP HEALTH AND DENTAL HYGIENE \\ WITH THE FIRST MOLAR PERMANENT CARRIES ON STUDENT PRIMARY \\ SCHOOL EAST PADANG DISTRICT \\ PADANG CITY)
}

\author{
Susi $^{1}$, Didin Kustantiningtyastuti ${ }^{2}$, Yona Ladyventini ${ }^{3}$
}

\begin{abstract}
Abstrak
Karies gigi dan radang gusi (gingivitis) merupakan penyakit gigi dan jaringan pendukungnya yang banyak dijumpai pada anak Sekolah Dasar di Indonesia. Penyebab timbulnya masalah gigi dan mulut masyarakat salah satunya adalah faktor perilaku atau sikap mengabaikan kebersihan gigi dan mulut. Penelitian ini bertujuan untuk mengetahui hubungan perilaku anak terhadap kesehatan dan kebersihan gigi dengan kejadian karies molar pertama permanen pada murid SDN 15 Kecamatan Padang Timur Kota Padang.

Desain penelitian ini adalah Cross Sectional Study. Penelitian ini dilakukan di Sekolah Dasar Negeri 15 Kecamatan Padang Timur Kota Padang Padang pada Januari 2012. Sampel penelitian ini adalah murid kelas IV, V, VI berjumlah 80 orang. Pengumpulan data dilakukan melalui kuesioner dan pemeriksaan gigi dengan analisis chi-square.
\end{abstract}

Kata Kunci : Karies Molar Pertama Permanen, Perilaku

\begin{abstract}
Dental caries and gum disease (gingivitis) is a disease which are often found in elementary school's student in Indonesia. One of the cause of the oral and dental problems is behavior factor or neglect of oral hygiene. This study aims to determine the relationship of children's behaviors to health and dental hygiene with caries incidence in permanent first molars in SDN 15 Eastern District of Padang.

The design of this study is the Cross Sectional Study. The research was conducted at the Elementary School District 15 East Padang Padang Padang in January 2012. This study sample was a student of class $I V, V$, VI amounted to 80 people. The data was collected through questionnaires and dental examinations by chi-square analysis.
\end{abstract}

Key Words : Permanent first molar caries, behavior

\footnotetext{
${ }^{1}$ Staf Pengajar Fakultas Kedokteran Gigi Universitas Andalas

${ }^{2}$ Dokter Gigi RS M. Djamil Padang

${ }^{3}$ Mahasiswa Fakultas Kedokteran Gigi Universitas Andalas
} 


\section{PENDAHULUAN}

Karies gigi dan radang gusi (gingivitis) merupakan penyakit gigi dan jaringan pendukungnya yang banyak dijumpai pada anak Sekolah Dasar di Indonesia. Keadaan ini cenderung meningkat setiap dasawarsa ${ }^{1}$. Banyak usaha yang telah dilakukan untuk menurunkan prevalensi karies namun usaha tersebut belum memberikan hasil yang signifikan karena masih tingginya prevalensi karies pada anak sekolah dasar ${ }^{2}$.

Karies disebabkan oleh multi faktor, salah satunya adalah faktor perilaku atau sikap mengabaikan kebersihan gigi dan mulut. Hal ini disebabkan karena kurangnya pengetahuan mengenai pemeliharaan kesehatan gigi dan mulut. Anak sangat tergantung pada orang dewasa dalam menjaga kebersihan dan kesehatan giginya. Pengetahuan anak mengenai kesehatan gigi lebih rendah dibandingkan dengan orang dewasa ${ }^{3}$.

Murid sekolah dasar berada pada periode gigi bercampur, dimana di dalam mulutnya terdapat dua jenis gigi yaitu gigi sulung dan gigi permanen. Karies menyerang gigi sulung dan gigi permanen. Gigi permanen yang paling sering terkena karies adalah molar pertama permanen ${ }^{4}$. Gigi Molar pertama permanen merupakan gigi yang penting pada susunan gigi geligi karena merupakan kunci oklusi. Gigi molar pertama permanen rahang erupsi pada umur 6- 7 tahun dan pembentukan akar gigi lengkap pada umur 9-10 tahun ${ }^{5}$.

Gigi molar pertama permanen banyak terserang karies segera setelah erupsi. Hasil penelitian di Inggris menyatakan anak pada usia 10 tahun sebanyak $62 \%$ telah mengalami karies gigi molar pertama permanen ${ }^{6}$. Hal ini disebabkan karena banyaknya pit dan fisur pada gigi molar permanen sehingga sisa makanan mudah menumpuk pada daerah ini sehingga memudahkan terjadinya karies pada gigi molar pertama permanen ${ }^{7}$.

Prevalensi hilangnya gigi molar pertama bawah cukup tinggi. Prevalensi hilangnya gigi molar pertama permanen karena karies adalah 70\%. Gigi molar pertama permanen erupsi sebelum gigi geligi susu tanggal dan gigi ini merupakan gigi yang tidak menggantikan gigi susu. Sering terjadi orang tua menganggap gigi ini adalah gigi sulung sehingga kalau gigi ini karies tidak dirawat dan dicabut karena menganggap penggantinya akan erupsi ${ }^{8}$.

Provinsi Sumatera Barat memiliki indeks DMF-T 5,25 dan menduduki posisi ke 6 tertinggi diantara 32 provinsi di Indonesia 9 . Prevalensi karies di Kota Padang adalah 58,4\%. Puskesmas 
Andalas Kota Padang adalah puskesmas dengan cakupan pelayanan karies tertinggi yaitu sebesar $13 \%^{10}$. Berdasarkan laporan screening yang dilakukan oleh Puskesmas Andalas, Sekolah Dasar dengan kejadian karies tertinggi adalah SDN 15 Kecamatan Padang Timur yaitu 24 murid terserang karies dari 26 murid yang diperiksa. Dari hasil observasi yang telah dilakukan ke SD tersebut, ditemukan 17 anak yang mengalami karies molar pertama permanen dari 30 anak yang diperiksa.

Berdasarkan alasan - alasan tersebut di atas penulis tertarik unuk meneliti suatu permasalahan yaitu hubungan perilaku anak terhadap kesehatan dan kebersihan gigi dengan kejadian karies molar pertama permanen pada murid Sekolah Dasar Negeri 15 Kecamatan Padang Timur Kota Padang tahun 2012.

\section{MATERI DAN METODE}

Disain penelitian yang digunakan adalah Cross sectional Study. Populasi pada penelitian ini adalah siswa kelas IV, V, VI Sekolah Dasar Negeri 15 Kecamatan Padang Timur Kota Padang. Karena jumlah populas kecil dari 100 maka digunakan metode Total Sampling.

Sampel dalam penelitian berjumlah 80 orang. Terdiri dari : a. Kelas IV: Jumlah siswa 25 orang.

b. Kelas V : Jumlah siswa 28 orang

c. Kelas VI : jumlah siswa 27 orang

Data primer diperoleh dari responden dengan cara wawancara menggunakan kuesioner yang terdiri dari variabel independen (hubungan perilaku anak terhadap kesehatan dan kebersihan gigi) dan variabel dependen (kejadian karies molar pertama permanen).

Kuesioner yang digunakan ada 3 bagian yaitu :

1. Bagian yang pertama tentang pengetahuan terdiri dari 13 item pertanyaan dimana jika jawaban benar diberi nilai (1) dan jawaban salah diberi nilai (0).

2. Bagian yang kedua tentang sikap terdiri dari 13 item pernyataan baik positif maupun negatif.

3. Bagian ketiga tentang kebiasaan terdiri dari 13 pertanyaan.

Data untuk karies molar pertama permanen didapat melalui pemeriksaan oleh peneliti. Selain itu juga dibantu oleh mahasiswa FakultasKedokteran Gigi yang telah diberi arahan sehingga mempunyai persepsi yang sama dengan peneliti. 
Analisis univariat dilakukan untuk melihat distribusi frekuensi dari variabel independen (Hubungan perilaku anak terhadap kesehatan dan kebersihan gigi) dan variabel dependen (kejadian karies molar pertama permanen). Analisis bivariat untuk mengetahui hubungan antara variabel independen dengan variabel dependen, dilakukan uji Chi Square dengan tingkat kepercayaan 95\%

\section{HASIL}

Kejadian karies Molar Pertama Permanen Responden

Tabel 1. Distribusi responden berdasarkan kejadian karies gigi molar pertama permanen

\begin{tabular}{lcc}
\hline $\begin{array}{c}\text { Kejadian karies } \\
\text { M1 Permanen }\end{array}$ & $\mathrm{n}$ & $\%$ \\
\hline Karies $(+)$ & 57 & 71,3 \\
\hline Karies $(-)$ & 23 & 28,8 \\
\hline Jumlah & 80 & 100 \\
\hline
\end{tabular}

Tabel 2. Distribusi Jumlah karies Molar Pertama Permanen

\begin{tabular}{ccc}
\hline $\begin{array}{c}\text { Jumlah Karies } \\
\text { Molar 1 }\end{array}$ & $\mathrm{n}$ & $\%$ \\
\hline 0 & 23 & 28,8 \\
\hline 1 & 16 & 20 \\
\hline 2 & 28 & 35 \\
\hline 3 & 7 & 8,8 \\
\hline 4 & 6 & 7,5 \\
\hline Total & 80 & 100 \\
\hline
\end{tabular}

Tabel 3. Distribusi Molar Pertama permanen Yang Sering Terkena karies

\begin{tabular}{ccc}
\hline Gigi Molar & $\mathrm{n}$ & $\%$ \\
\hline 1.6 & 16 & 13,7 \\
\hline 2.6 & 22 & 18,8 \\
\hline 3.6 & 38 & 32,5 \\
\hline 4.6 & 41 & 35 \\
\hline Jumlah & 117 & 100 \\
\hline
\end{tabular}

Tabel 4. Pengetahuan Responden

\begin{tabular}{lcc}
\hline $\begin{array}{c}\text { Tingkat } \\
\text { Pengetahuan }\end{array}$ & $\mathrm{n}$ & $\%$ \\
\hline Tinggi & 16 & 20 \\
\hline Sedang & 60 & 75 \\
\hline Rendah & 4 & 5 \\
\hline Jumlah & 80 & 100 \\
\hline
\end{tabular}

Tabel 5. Distribusi responden berdasarkan sikap menjaga kesehatan dan kebersihan gigi

\begin{tabular}{ccc}
\hline \multicolumn{1}{c}{ Sikap } & $\mathrm{n}$ & $\%$ \\
\hline Positif & 32 & 40 \\
\hline Negatif & 48 & 60 \\
\hline Jumlah & 80 & 100 \\
\hline
\end{tabular}

Tabel 6. Distribusi responden berdasarkan kebiasaan menjaga kesehatan dan kebersihan gigi

\begin{tabular}{lcc}
\hline Kebiasaan & $\mathrm{n}$ & $\%$ \\
\hline Baik & 27 & 33,8 \\
\hline Tidak baik & 53 & 66,3 \\
\hline Jumlah & 80 & 100 \\
\hline
\end{tabular}

Tabel.7. Hubungan tingkat pengetahuan terhadap kesehatan dan kebersihan gigi dengan kejadian karies

\begin{tabular}{|c|c|c|c|c|c|c|}
\hline \multirow{3}{*}{$\begin{array}{c}\text { Tingkat } \\
\text { Pengetahuan }\end{array}$} & \multicolumn{4}{|c|}{ Kejadian Karies gigi } & \multicolumn{2}{|c|}{ Jumlah } \\
\hline & \multicolumn{2}{|c|}{ Karies (+) } & \multicolumn{2}{|c|}{ Karies (-) } & & \\
\hline & $\mathbf{n}$ & $\%$ & $\mathrm{n}$ & $\%$ & $\mathrm{n}$ & $\%$ \\
\hline Tinggi & 9 & 56,3 & 7 & 43,8 & 16 & 100 \\
\hline Sedang & 45 & 75 & 15 & 25 & 60 & 100 \\
\hline Rendah & 3 & 75 & 1 & 25 & 4 & 100 \\
\hline Jumlah & 57 & 71,3 & 23 & 28,8 & 80 & 100 \\
\hline
\end{tabular}


Tabel 8. Hubungan sikap dalam menjaga kesehatan dan kebersihan gigi dengan kejadian karies molar pertama permanen

\begin{tabular}{lllllll}
\hline \multirow{2}{*}{ Sikap } & \multicolumn{3}{l}{ Kejadian Karies gigi } & \multicolumn{2}{l}{ Jumlah } \\
\cline { 2 - 5 } & \multicolumn{2}{l}{ Karies ( + ) } & \multicolumn{2}{l}{ Karies ( - ) } & \\
\cline { 2 - 6 } & $\mathrm{n}$ & $\%$ & $\mathrm{n}$ & $\%$ & $\mathrm{n}$ & $\%$ \\
\hline Positif & 21 & 65,6 & 11 & 34,4 & 32 & 100 \\
\hline Negatif & 36 & 75 & 12 & 25 & 48 & 100 \\
\hline Jumlah & 57 & 71,3 & 23 & 28,8 & 80 & 100 \\
\hline $\mathrm{P}=0,512$ & & & & &
\end{tabular}

Tabel 9. Hubungan kebiasaan dalam menjaga kesehatan dan kebersihan gigi dengan kejadian karies molar pertama permanen

\begin{tabular}{lcccccc}
\hline \multirow{2}{*}{ Kebiasaan } & \multicolumn{3}{c}{ Kejadian Karies gigi } & \multicolumn{2}{l}{ Jumlah } \\
\cline { 2 - 6 } & \multicolumn{2}{c}{ Karies $(+)$} & \multicolumn{2}{c}{ Karies $(-)$} & & \\
\cline { 2 - 6 } & $\mathrm{n}$ & $\%$ & $\mathrm{n}$ & $\%$ & $\mathrm{n}$ & $\%$ \\
\hline Baik & 20 & 74,1 & 7 & 25,9 & 27 & 100 \\
\hline Tidak baik & 37 & 69,8 & 16 & 30,2 & 53 & 100 \\
\hline Jumlah & 57 & 71,3 & 23 & 28,8 & 80 & 100 \\
\hline \multicolumn{2}{c}{$\mathrm{P}=0,891$} & & & & &
\end{tabular}

\section{PEMBAHASAN}

\section{Karies Molar Pertama Permanen}

Berdasarkan hasil penelitian yang dilakukan menunjukan bahwa sebanyak $71,3 \%$ murid SDN 15 Kecamatan Padang Timur mengalami karies molar pertama permanen. Dari hasil penelitian didapatkan bahwa gigi molar yang paling sering mengalami karies adalah gigi molar pertama permanen rahang bawah yaitu sebesar $67,5 \%$.

Gigi permanen yang pertama kali erupsi adalah gigi molar pertama rahang bawah. Gigi ini erupsi pada saat anak berusia 6 tahun dan gigi molar memiliki bentuk yang khas pada permukaan oklusalnya mempunyai pit dan fissure. Hal ini memudahkan perlekatan plak dan debris sehingga mudah terjadi karies. Hasil penelitian ini sejalan dengan hasil penelitian Eddra Yunita yaitu 74,5\% murid SDN 13 Batu Manjulur mengalami karies gigi pada geraham besar pertama.

Pengetahuan tentang Kesehatan dan Kebersihan Gigi

Berdasarkan hasil penelitian didapatkan sebanyak $5 \%$ murid SDN 15 kecamatan Padang Timur memiliki pengetahuan yang rendah tentang kesehatan dan kebersihan gigi. Pada penelitian ini diketahui bahwa sebagian besar murid memiliki pengetahuan sedang tentang kesehatan dan kebersihan gigi. Hal ini dapat dipengaruhi oleh peran orang tua dan guru dalam meningkatkan pengetahuan anak seperti dengan memberikan penyuluhan tentang upaya kesehatan gigi di sekolah. Selain itu kegiatan UKGS yang dilakukan oleh pihak puskesmas juga memberikan peranan penting dalam meningkatkan pengetahuan anak.

Penelitian ini sejalan dengan penelitian yang dilakukan oleh Ady Saputra di Kecamatan Sungai Penuh yang memperoleh hasil hanya 32,4 \% saja 
murid SD yang mempunyai pengetahuan rendah.

\section{Sikap Anak Dalam Menjaga}

\section{Kesehatan dan Kebersihan Gigi}

Berdasarkan hasil penelitian $\begin{array}{llllll}\text { didapatkan } & 60 & \% & \text { murid } & \text { SDN } & 15\end{array}$ kecamatan padang Timur mempunyai sikap negatif dalam menjaga kesehatan dan kebersihan gigi. Mulut. Pada hasil penelitiam diketahui pengetahuan anak yang sedang terhadap pengetahuan dalam menjaga kesehatan dan kebersihan gigi adalah $75 \%$. Hal ini dapat mempengaruhi sikap negatif anak. Sikap anak dipengaruhi oleh pengetahuannya mengenai kesehatan gigi dan kebersihan gigi dan mulut. Hasil penelitian ini sejalan dengan penelitian yang dilakukan oleh Eddra Yunita di SDN 13 Batu Manjulur Kabupaten Sijunjung yang menemukan bahwa 57,4 \% murid mempunyai sikap yang negatif.

\section{Kebiasaan Menjaga Kesehatan dan} Kebersihan Gigi

Berdasarkan hasil penelitian menunjukkan bahwa sebanyak 66,3\% murid SDN 15 Kecamatan Padang Timur mempunyai kebiasaan menjaga kesehatan dan kebersihan gigi yang tidak baik. Kebiasaan dipengaruhi oleh pengetahuan dan sikap. Kebiasaan anak juga dipengaruhi oleh lingkungan keluarganya. Hasil penelitian ini sejalan dengan penelitian yang dilakukan oleh Eddra Yunita di SDN 13 Batu Manjulur Kabupaten Sijunjung yaitu sebanyak 53,2 $\%$ murid mempunyai kebiasaan menyikat gigi yang tidak baik.

\section{Hubungan Pengetahuan Tentang} Kesehatan dan Kebersihan gigi dengan Kejadian Karies Molar Pertama Permanen

Berdasarkan hasil penelitian diketahui sebagian besar $75 \%$ murid yang mempunyai pengetahuan sedang menderita karies molar pertama permanen, $75 \%$ murid yang memiliki pengetahuan rendah menderita karies molar pertama permanen dan 56,3\% murid berpengetahuan tinggi menderita karies molar pertama permanen. Secara statistik tidak ada perbedaan yang bermakna dari proporsi kejadian karies molar pertama permanen antara murid yang berpengetahuan tinggi dengan murid yang berpengetahuan rendah.

Menurut analisa yang dilakukan, tingginya kejadian karies ini disebabkan karena pengetahuan tentang kesehatan dan kebersihan gigi yang baik baru didapat sekarang, sementara karies sudah dialami sebelumnya karena gigi molar pertama permanen sudah erupsi sejak umur 6 tahun. Selain itu juga ada 
kemungkinan faktor lain seperti kandungan fluor pada air minum, pola makan dan pengalaman karies ${ }^{7}$.

\section{Hubungan Sikap Dalam Menjaga Kesehatan dan Kebersihan Gigi Dengan Kejadian Karies Molar Pertama Permanen}

Dari hasil penelitian yang dilakukan didapatkan $65,6 \%$ murid yang mempunyai sikap positif menderita karies molar pertama permanen. Secara statistik tidak terdapat hubungan yang bermakna dari proporsi kejadian karies molar pertama permanen antara murid yang bersikap positif dengan murid yang bersikap negatif.

Hal ini bisa disebabkan karena sikap dalam menjaga kesehatan dan kebersihan gigi baru terbentuk setelah mengalami karies molar pertama permanen, perilaku keluarga dalam menjaga kesehatan dan kebersihan gigi, fluor pada air minum, pola makan, pengalaman karies ${ }^{7}$, serta tingkat pendidikan orang tua ${ }^{11}$.

\section{Hubungan Kebiasaan Dalam Menjaga} Kesehatan dan Kebersihan Gigi Dengan Kejadian Karies Molar pertama Permanen.

Dari hasil penelitian yang dilakukan didapatkan sebanyak 74,1\% murid yang mempunyai kebiasaan menjaga kesehatan dan kebersihan gigi yang baik menderita karies molar pertama permanen. Secara statistik tidak terdapat hubungan yang bermakna dari proporsi kejadian karies molar pertama permanen antara murid yang memiliki kebiasaan menjaga kesehatan dan kebersihan gigi yang baik dengan murid yang memiliki kebiasaan yang tidak baik.

Hal ini disebabkan karena peneliti tidak menanyakan secara spesifik mengenai teknik menyikat gigi. Selain waktu menyikat gigi, teknik menyikat gigi juga sangat berperan dalam menjaga kebersihan gigi. Walaupun waktu menyikat gigi sudah benar, tetapi tekniknya tidak benar tidak akan menjamin kebersihan gigi yang optimal. Penyebab lainnya yaitu karena kebiasaan dalam menjaga kesehatan dan kebersihan gigi baru terbentuk setelah mengalami karies molar pertama permanen, bentuk anatomi gigi molar satu yang memiliki pit dan fissure yang dalam sehingga sulit dibersihkan.

\section{KESIMPULAN}

1. Sebagian besar responden yaitu $75 \%$ mempunyai pengetahuan sedang tentang kesehatan dan kebersihan gigi pada murid SDN 15 Kecamatan Padang Timur Kota Padang.

2. Sebagian besar responden yaitu $60 \%$ mempunyai sikap negatif dalam 
menjaga kesehatan dan kebersihan

gigi pada murid SDN 15 Kecamatan

Padang Timur Kota Padang.

3. Sebagian besar responden yaitu $66,3 \%$ mempunyai kebiasaan yang tidak baik dalam menjaga kesehatan dan kebersihan gigi pada murid SDN 15 Kecamatan Padang Timur Kota Padang.

4. Sebagian besar responden yaitu $71,3 \%$ menderita karies molar pertama permanen pada murid SDN 15 Kecamatan Padang Timur Kota Padang.

5. Sebagian besar responden yaitu $35 \%$ menderita karies pada dua molar pertama permanen pada murid SDN 15 Kecamatan Padang Timur Kota Padang.

6. Sebagian besar responden yaitu 67,5\% menderita karies pada molar pertama permanen rahang bawah pada murid SDN 15 Kecamatan Padang Timur Kota Padang.

7. Tidak terdapat hubungan antara pengetahuan tentang kesehatan dan kebersihan gigi dengan kejadian karies molar pertama permanen pada murid SDN 15 Kecamatan Padang Timur Kota Padang.

8. Tidak terdapat hubungan antara sikap dalam menjaga kesehatan dan kebersihan gigi dengan kejadian karies molar pertama permanen pada murid SDN 15 Kecamatan Padang Timur Kota Padang.

9. Tidak terdapat hubungan antara kebiasaan dalam menjaga kesehatan dan kebersihan gigi dengan kejadian karies molar pertama permanen pada murid SDN 15 Kecamatan Padang Timur Kota Padang.

\section{KEPUSTAKAAN}

1. Dwiati, Laksmi.2004. Pengaruh Model Pencegahan karies Gigi Anak dan Gingivitis Terhadap Status kesehatan Gigi Anak Sekolah dan Efisiensi Sumber Daya program UKGS di Provinsi DKI Jakarta tahun 2002. Jakarta : Jurnal PDGI

2. Supartinah, S. 2001. Peranan Cariogram dalam Pencegahan Karies Baru pada Anak. Yogyakarta : UGM

3. World Health Organization. 2008. Cit fankari

4. Soemarsono, SH. 1991. Masalah karies gigi anak. Buku Naskah Ilmiah KPPIKGIX. Jakarta

5. Paramitha, P. 2000. Memahami Pertumbuhan Kelainan Gigi Anak. Trubus : Agriwidya

6. Andlow, R. J. 1992. Perawatan Gigi Anak. Terjemahan Agus Djaya dari A Manual of Paedodontics (1987). Jakarta : Widya Medica

7. Pintauli, S dan Hamada, T. 2008. Karies Gigi. Medan : USU Press

8. Albadri S, Zaitoun H, McDonnell ST, Davidson L.E. 2007. Extracton of First Permanent Molar Teeth ; Result from Three Dental Hospitals.

9. Departemen Kesehatan RI.2007. Riset Kesehatan Dasar. Jakarta : Departemen Kesehatan RI

10. Laporan Tahunan Seksi Gizi dan Kesehatan Khusus. 2010. Dinas Kesehatan Kota Padang 
11. Meli. 2005. Karies Gigi Molar Pertama Permanen pada Anak; Permasalahan dan penanggulangannya. Medan : FKG USU 